\title{
汐路丸デイーゼル主機関自動調速系の解析
}

\section{Analysis of Speed Control System of the Shioji-Maru's Main Diesel Engine.}

森下隆 (東京嘀船大学)

\section{1. 緒言}

東京商船大学練習船汐路丸デイーゼル主機関の遠隔㙅作装㯰の計画に先立つて、この機関の自 動調速系の現状を解析した。

\section{2. 自動調速系の構成}

汐路丸デイーゼル主機関自動調速系の構成を図・1亿示す。プロペラ軸と值結されたクランク 軸回転角速度を遠心力式回転角速度検出器に よつて遠心力に変換し、ての遠心力はおさ光 ばねの力と比較され、その不平衡力分だけス リーブが変位し、てのスリーブの変位量は低 域沪波器在径て然料油噴射ポンプ・プランヂ ヤーの有效行程を変化させる。燃料油噴射ポ ンプ・プランヂャーはクランク軸回転角速度 に比例して回転するカムによつて突き上げら れ、燃料油噴射管わよび然料油噴射弁を経て 燃料油を主機気筒内に噴射する。気筒内噴 射された燃料油はその熱エネルギーを機械仕 事に変換し、機関およびプロペラの回転部分 の加速、機関の摩嚓仕事きょび船を推進する

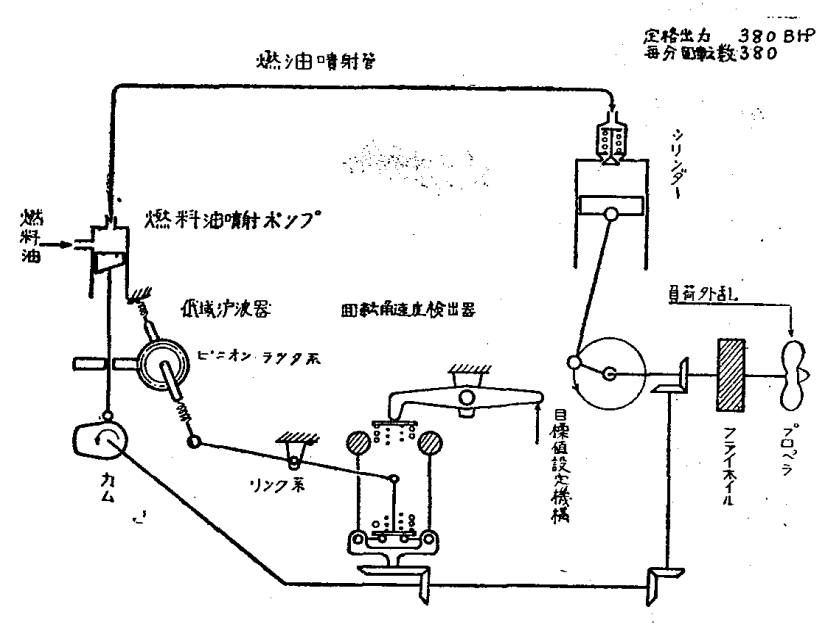

第 1 図 汐路丸ディーゼル主機関自動 調達速系の棈成 仕事として消費される。速度調整ハンドルは目標回転角速度の設定部である。

\section{3. 要素の動特性}

自動調速系の解析を容易にするために、要素特性は全て線型化した。

$3 \cdot 1$ 燃料油噴射ポンプの動特性・燃料油噴射ポンプから吐出される単位時間当りの燃料油量 は主機クランク軸回転角速度とプランヂャー有効行程の積に比例する。

$$
q_{f(t)}=K_{1} \cdot w_{(t)} \cdot x_{(t)}
$$

式(1)を線型化する。

$$
\frac{d q_{f}}{d t}=\left(-\frac{\partial q_{f}}{\partial w}\right)_{x_{0}} \cdot \frac{d w}{d t}+\left(\frac{\partial q_{f}}{\partial x}\right)_{w_{0}} \cdot \frac{d x}{d t}
$$

式(2)を $L$ 変換する。

$$
q_{f(s)}=\left(\frac{\partial q_{f}}{\partial w}\right)_{x 0} \cdot w_{(s)}+\left(\frac{\partial q_{f}}{\partial x}\right)_{w 0} \cdot x_{(s)}
$$

こてで 
$q_{f(s)}$ : 燃料油噴射ポンプの吐旦量

$w_{(t)}$ : 主機回転角速度

$x_{(t)}$ : 燃料油噴射ポンプ・プランヂヤ一有效行程

$K_{1}$ : 定数

$$
K_{1}=\rho \cdot a \cdot \frac{z}{2 \pi}
$$

$\rho$ : 燃料油の密度

$a$ : 燃料油噴射ポンプ・プランヂヤ一断面積

$\mathrm{gr} / \mathrm{Cmi}^{3}$

$$
\begin{array}{lll}
z: \text { 定数 } & z=1 & \text { 2サイクル機関 } \\
& z=0.5 & 4 \text { 4イクル機関 }
\end{array}
$$

3 ・2 熱力学系・燃料油噴射ポンプから吐出された燃料油は燃料油噴射管および燃料油噴射弁 をむぎ時閒 $\tau_{1}$ をもつて通り気筒内に噴射され然焼し熱エネルギーに変換する。気筒内で単位時 間になされる仕事量は。気筒内に単位時間に噴射された然料油量に比例する。

$$
W_{(s)}=\eta_{t h} \cdot \frac{\sigma}{A} \cdot \frac{e^{-\tau_{1} s}}{T_{1} s+1} q_{f(s)}
$$

ここで、

$W$ : 気筒内で単位洔間になす任事量

$\eta_{t h}:$ 機関の熱効率

$\sigma$ ：燃料游の発熱量

$\mathrm{kcal/gr}$

1/A：熱の仕事当量

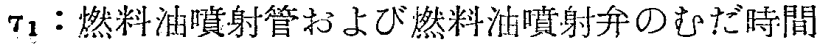
$427 \mathrm{~kg}-\mathrm{m} / \mathrm{kcal}$

$T_{1}$ : 燃燒の時定擞

$\sec$

sec

単位時間内になされる仕事量は負何トルクとプロペラ軸国転角速度との積である。

$W_{(t)}=T_{(t)} \cdot w_{(t)}$

式(5)を線型化する。

$\left.\frac{d W_{(t)}}{d t}=\left(\frac{\partial W}{\partial T}\right)_{w_{0}} \cdot \frac{d T}{d t}+\frac{\partial W}{\partial w}\right)_{T_{0}} \cdot \frac{d w}{d t}$

式(6)を $L$ 変換する。

$$
W_{(s)}=\left(\frac{\partial W}{\partial T}\right)_{w s} \cdot T_{(s)}+\left(\frac{\partial W}{\partial w}\right)_{T_{0}} \cdot w_{(s)}
$$

式(4)と式(6)汃ら次式を得る。

$$
\boldsymbol{T}_{(s)}=\eta_{t h} \cdot \frac{\sigma}{A} \cdot \frac{1}{\left(\frac{\partial W}{\partial T}\right)_{w 0}} \cdot \frac{1}{T_{1} s+1} q_{f(s)}-\frac{\left(\frac{\partial W}{\partial w}\right)_{\boldsymbol{T}_{0}}}{\left(-\frac{\partial W}{\partial W}\right)_{w 0}} w_{(s)}
$$

ここで、

$T:$ 主機タランク軸に加わるトルク $\mathrm{kg}-\mathrm{m}$

3 ・3 回転体の力学系・プロペラ軸回転角速度は次式によつてあらわされる。

$$
T_{(t)}=J \frac{d w}{d t}+\left\{\left(\frac{\partial T_{m}}{\partial w}\right)_{w 0}+\left(\frac{\partial T_{\ell}}{\partial w}\right)_{w 0}\right\} w_{(t)}
$$

式(9)を $L$ 変換する。

$$
w_{(s)}=\frac{1}{J_{s}+\left(\frac{\partial T_{m}}{\partial w}\right)_{w 0}+\left(\frac{\partial T_{l}}{\partial w}\right)_{w_{0}}} T_{(s)}
$$


こてで、

$J$ ：主機回転部分、フライホイル杼よびプロペラの慣性能率 $\mathrm{kg}-\mathrm{sec}^{2}-\mathrm{m}$

$T_{m}:$ 機械損トルク

$\mathrm{kg}-\mathrm{m}$

$T_{e}:$ 負荷トルク

$\mathrm{kg}-\mathrm{m}$

$3 \cdot 4$ 回転角速度蚞出機構の䡃;特性・プロペ ラ軸の回転角速度は歯車比 $N$ なる函車列芷経 て、遠心力式回転角速度検出器の主転に伝達さ れる。遠心力式回転角速度娭出器の略図展図・ 2 亿示す。

主機回転角速度と遠心力との閔係搌次に示 す。

$$
\begin{aligned}
C_{(t)} & =\frac{\boldsymbol{M}}{\boldsymbol{g}} \cdot \boldsymbol{r}_{(t)} \cdot w_{\mathbf{1}}{ }^{2}(t) \\
& =K^{2} \cdot \boldsymbol{r}_{(t)} \cdot w^{2}(t)
\end{aligned}
$$

式(11)のそれぞれの変化分をとる。

$$
\frac{d C_{(t)}}{d t}=K_{2} w_{0}{ }^{2} d r+2 K_{2} r_{0} w_{0} \frac{d w}{d t} \cdots(12)
$$

式(12)で求めた遠心力の変化分はばねを件縮さ せる力に均合う。

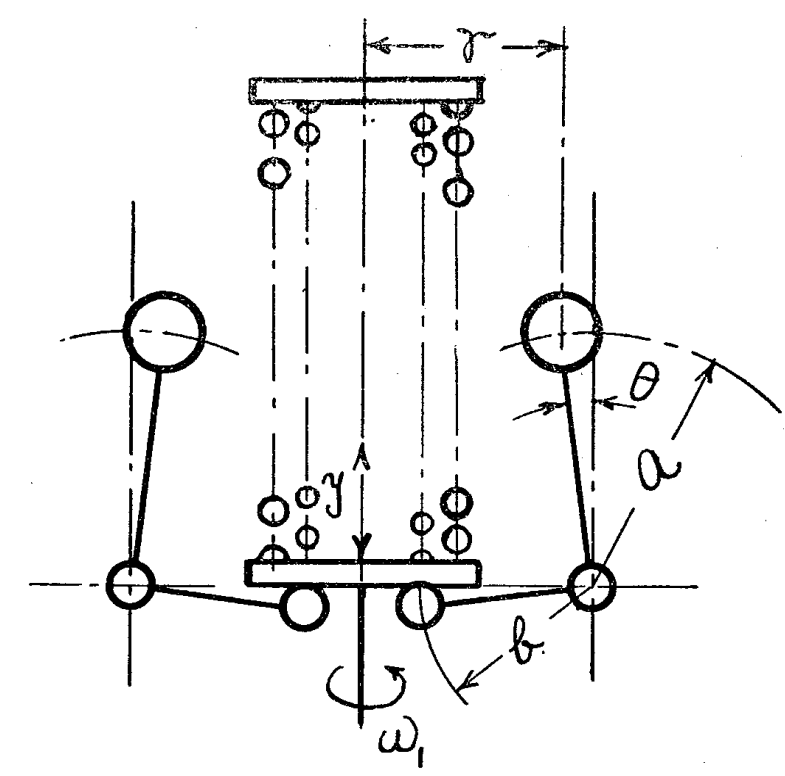

第 2 図 回転角速度検出機棈

$$
F_{(s)}=2 K_{2} w_{0}^{2} y_{(s)}+\frac{4 a}{b} K_{2} r_{0} w_{0} w_{(s)}
$$

ばねに加わる力の変化分とスリーブの変位量との関係は、スリーブおおよびスリーブより低域 沪波器にいたるリンクの重量を質量項スリーブおよびリンク軸受の摩擦を粘性摩係数項およびス リー-ブに加わるばね力をばね係数項とする二次微分方程式によつてあらわされる。

$$
F_{(t)}=\frac{m}{g} \cdot \frac{d^{2} y}{d t^{i}}+n \frac{d y}{d t}+k y
$$

式(14)を $L$ 変換する。

$$
y_{(s)}=\frac{1}{\frac{m}{g} s^{2}+n s+k} F_{(s)}
$$

ここで

$C_{(t)}:$ 遠心力

$F_{(t)}:$ ばねと加わる力

$M:$ 重鍾の重さ

$w_{1(t)}:$ 調速機主軸の回転角速度 $\mathrm{kg}$

$\boldsymbol{r}_{(t)}:$ 重錘の回転半径 $\mathrm{rad} / \mathrm{sec}$

$y_{(t)}:$ スリーブの変位量 $\mathrm{cm}$

$\mathrm{m}$ : スリーブおよびスリーブより低域沪波器にいたるリンクの重さ $\mathrm{cm}$

$n$ : スリーブ执よびリンク軸受の粘性摩擦係擞 $\mathrm{kg}$

$k:$ スリーブに加わるば就の゙ね係数 $\mathrm{kg} / \mathrm{rad} / \mathrm{sec}$

$$
K_{2}: \frac{M}{g} N^{2}, \quad N=\frac{w_{1(t)}}{w_{(t)}}
$$

$\mathrm{kg} / \mathrm{cm}$

$2 \cdot 5$ 低域沪波器の動特性・デイーゼル機関の回転角速度は負荷外乱の変化、目標回転角速度 
の設定值変更および機関の各気筒内の間けつ的な燃焼に起因するトルクによつて変化する。機関 の自動調速機笽は前 2 者に対してのみ㗢くもので後者に対しては作動してはならない。しかる に、機関の回転力学系の時定数方沘較的小さく、かつ回転角速度検出器の自然振動数少此較的大 きい系では後者による回転角速度の変化分を回転角速度検出器によつて蚞出し燃料油噴射ポンプ

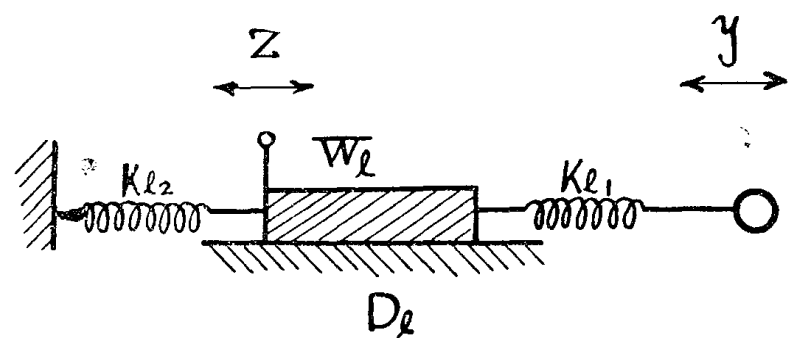

第3図低域污波器の原理図 に帰還することがある。てれを避けるために 比較的周波数の低い前 2 者による回転角速度 の変化分のみを燃料油噴射ポンプに帰還し、 此較的周波数の高い後者による回転解速度の 変化分のみを通さない機能をもつた低域泊波 器を用いる。乙の機楺は図・3に示すよう そ、その作動は二次微分方程式によつてあら わされる。

$$
y_{(t)}=\frac{W_{l}}{g} \cdot \frac{d Z}{d t^{2}}+D_{l} d Z \frac{d Z}{d t}\left(K_{l 1}+K_{l 2}\right) Z
$$

式(16)を $L$ 変換する。

$$
Z_{(s)}=\frac{1}{\frac{W_{l}}{g} s^{2}+D_{l} s+\left(K_{l 1}+K_{l 2}\right)} y_{(s)}
$$

こてで、

$$
W_{e}: \text { 低域泝波器の重さ }
$$

$D_{e}:$ 低域派波器の粘性摩擦係数

$K_{61}, K_{l 2}:$ 低域泊波器のば水係数

$Z_{(t)}:$ 低域泊波器出力端の変位量

$3 ・ 6$ リンク比・低域沪波器の出力端から燃料油噴射ポンプ の有效行程まで、リンク機構およびピニオン・ラック機構を経 て信号が伝達される。然料油噴射ポンプ・プランヂャーおよび ピニオン・ラック機構を図・4 亿示す。

$$
x_{(t)}=\frac{\delta L}{R} \tan \alpha \cdot Z_{(t)}
$$

式(18)を $L$ 変換する。

$$
X_{(s)}=\frac{\delta L}{R} \tan \alpha \cdot Z_{(s)}
$$

こてで、

$$
L \text { :リンク此 }
$$

$R:$ ピニオン半径

$\mathrm{cm}$

$\alpha:$ プランヂャーヘリカル溝傾度

$\delta:$ プランヂヤー半径

$\mathrm{cm}$

$3 ・ 7$ ブロツク線図・上記の諸項において求めた各要素の特

$\mathrm{kg} / \mathrm{cm} / \mathrm{sec}$

$\mathrm{kg} / \mathrm{cm}$

$\mathrm{cm}$

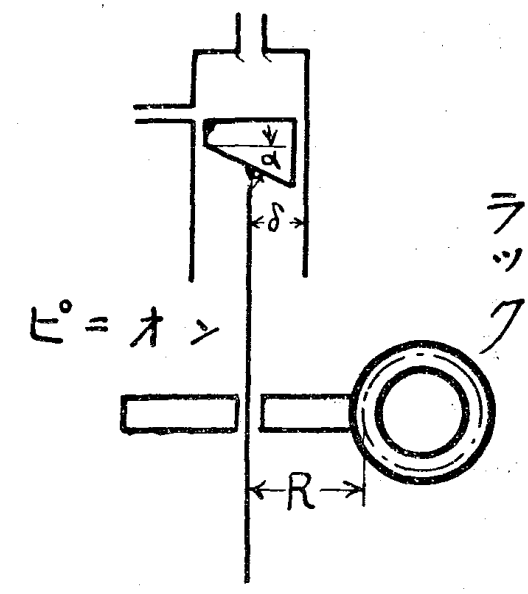

第 4 図 燃料油噴射尔 ンブの胳図

性をブロック線㘡に画き、乙れを信号の伝達順序にしたがつて結合したものが図・5である。四 に示めされている数值は機関の $3 / 4$ 負荷運転における計算值である。 
4. 系 の 特 性

図・5に示したブロツク線図から、3/4目荷時における計算值を用いて系の特性を求めた。この 計算結果を確めるために汐路丸デイーゼル主機関について航海実験を行つた。

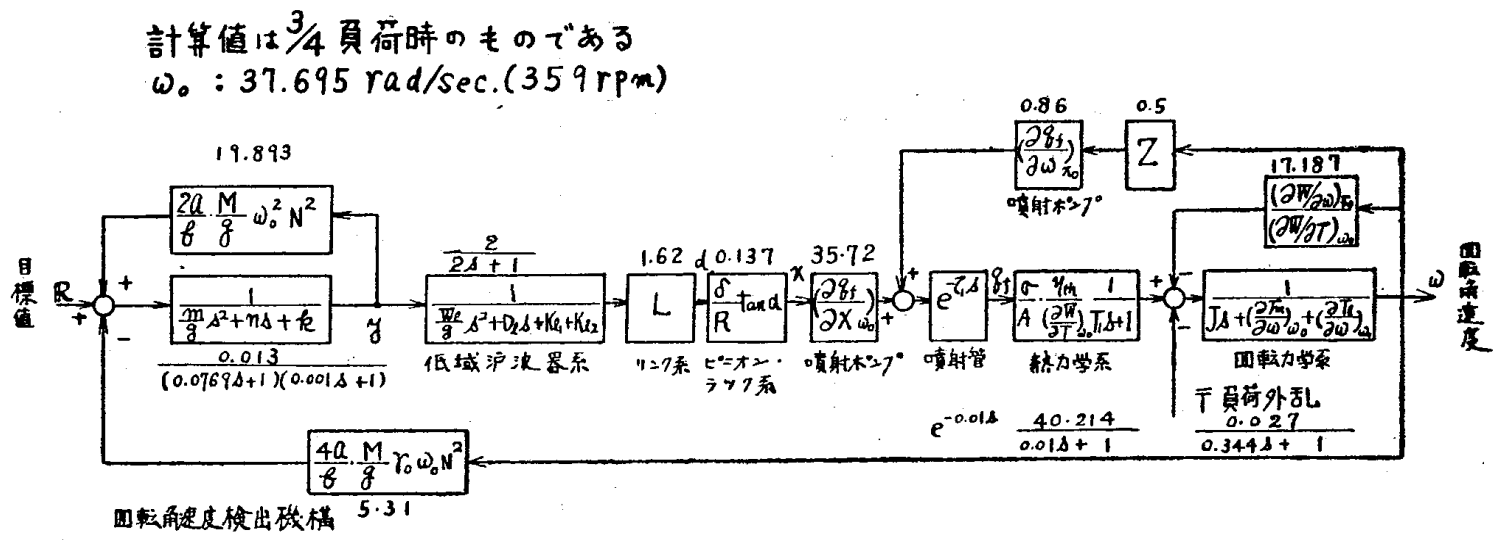

第 5 図 泝路丸ディーゼル主機關自動調速系のブロック線図

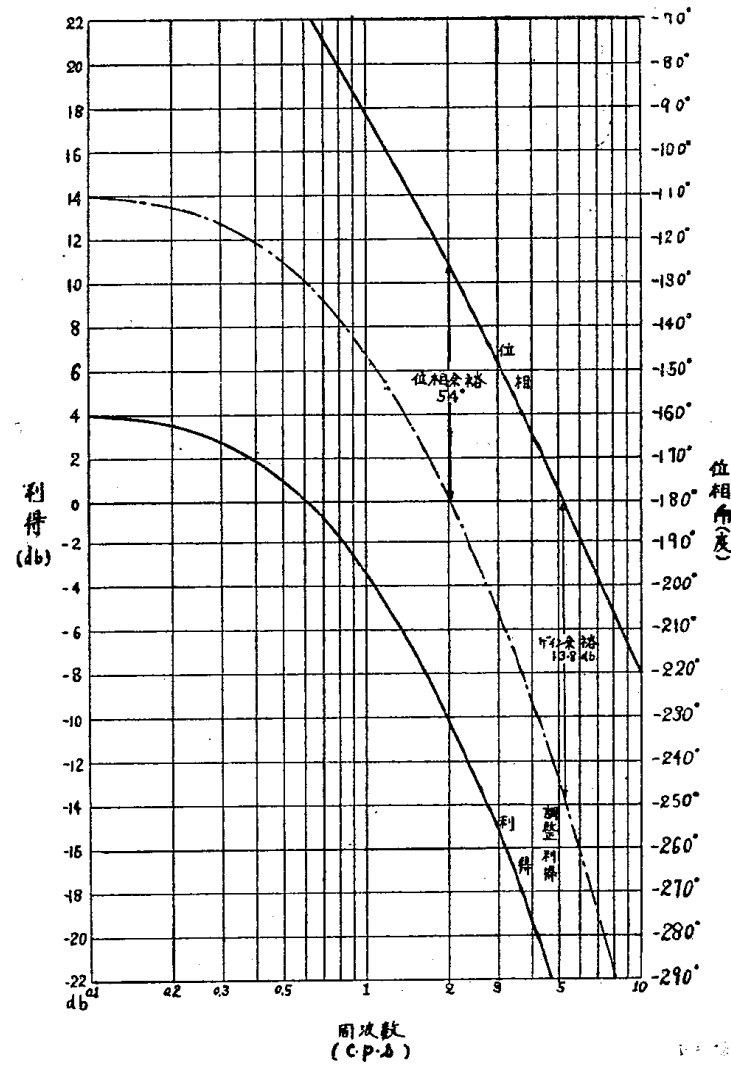

6 図 回路一巡周波数伝達関数の周波 数特性

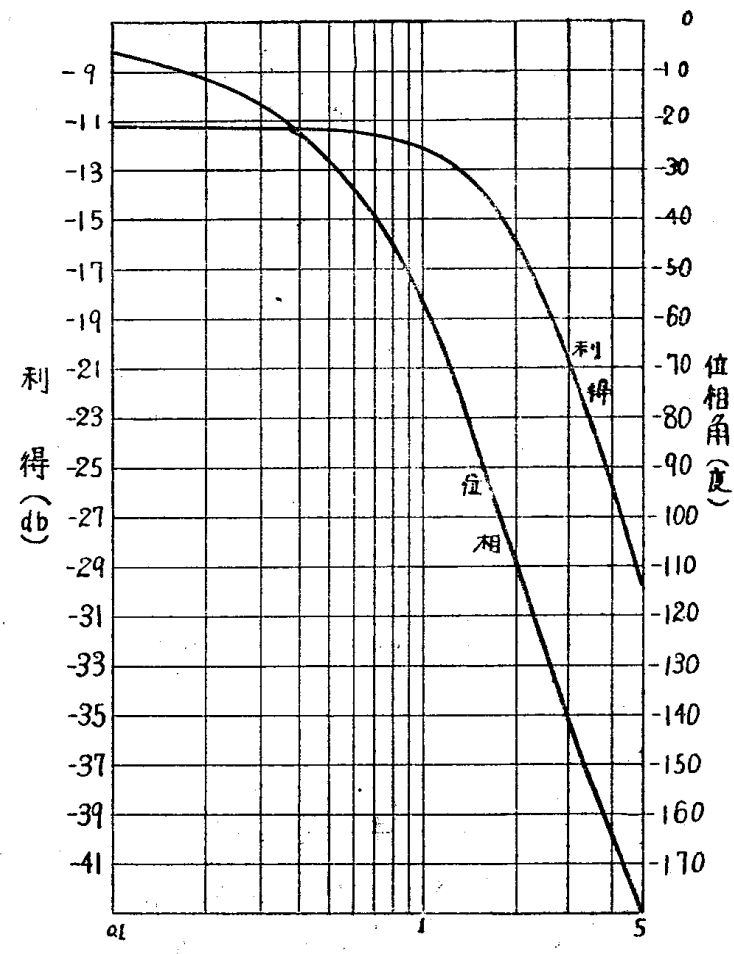

周波数

第 7 図 目標值変更に対する機関回転角 速度の周波数特性

この系の回路一巡局波数伝達関数の周波数特性を図・6亿示す。負荷変化がないとき、目標值 変更に対する機関回転角速度の周波数特性、すなわち、目標值に対する制御量の閉回路周波数云 達関数の周波数特性を図・7 亿示す。図・8 は負荷外乱に対する俶御量の閉回路周波数伝達関数 の周波数特性を示す。図・9は目標値変更に対する機関回転角速度の過渡応答計算結果および実 験結果を示す。 


\section{5. 考 察}

汐路丸デイーゼル主機関自動調速系の現状につ いて考察し、船舶用デイーゼル主機関の自動調速 系の計画および調整についての一手法:を提案し た。

$5 ・ 1$ 燃料油噴射ポンプ・燃料油噴射ポンプの 動特性は武(3)にようてあらわされ、図・5のブロ ツク線図からも明らかであるように、機関回転角 速度ぶ燃料油噴射ポンプ要素を通じて前向き径路 そ正州還している。発電機駆動用ディーゼル機関 の回転力学系は一般にその慣性能率が大きく、粘 性項が小さいが、船舶用デイーゼル主機関の回転 力学系の慣性能率は此較的小さく、粘性項は比較 的大きいので燃料油噴射ポンプの正帰還によつて 系の安定度は若干減少するが不安超系となるとと は殆んどない。汐路丸主機関は自動調速装置がな くても自己平衡性をもつ。すなわち、図・5のブ ロツク線図において、主业還回路がない膓合、負 荷外乱に対する回転争速度の関係は次式であらわ される。

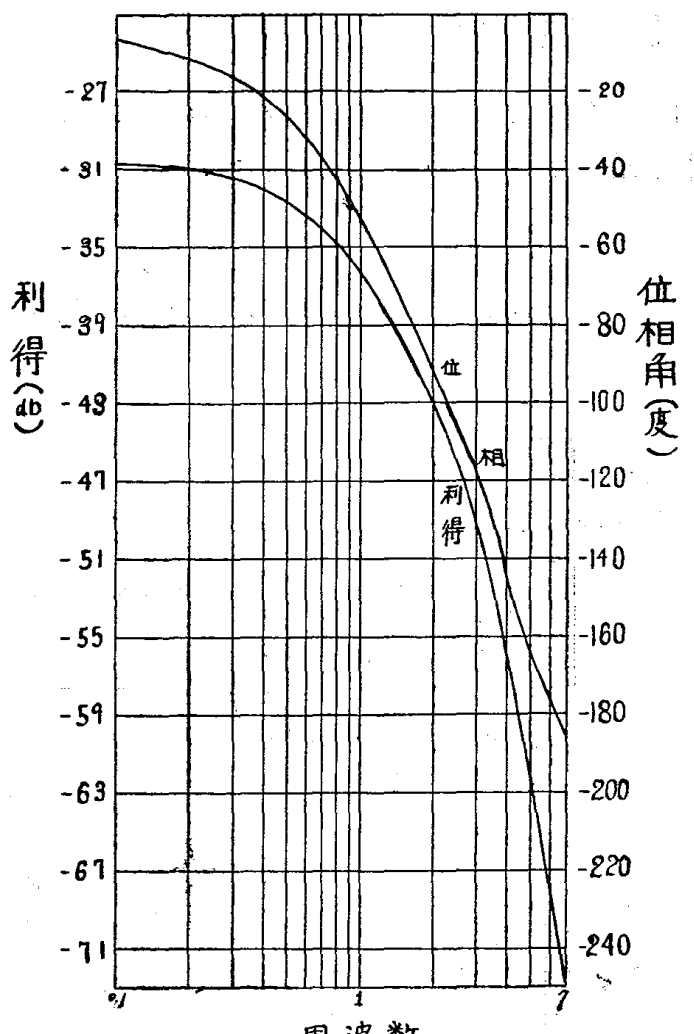

周波数

第 8 図 負荷外乱に対する機関回転 角速度の周波数特性

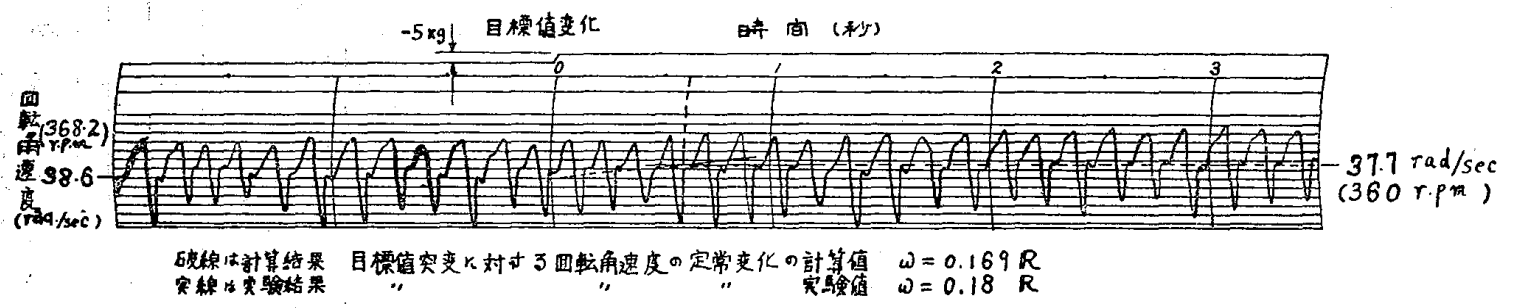

第 9 図，目標值突変に対する機関回転角速度過渡応答計算結果抒よび事験結果

$$
=\frac{\frac{w_{(s)}}{T_{e(s)}}}{T_{s}+\left(\frac{\partial T_{m}}{\partial w}\right)_{w_{0}}+\left(\frac{\partial T_{l}}{\partial w}\right)_{w_{0}}+\frac{1}{\left(\frac{\partial W}{\partial w}\right)_{r_{0}}-Z\left(\frac{\partial q_{f}}{\partial w}\right)_{x_{0}} \cdot \frac{\sigma}{A} \cdot \frac{\eta_{t h}}{\left(\frac{\partial W}{\partial T}\right)_{w_{0}}} \cdots(20)}}
$$

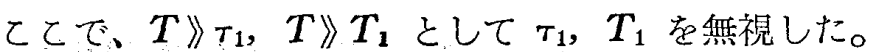

自動調速装置がなくても自己平衡性をもつための条件は式(20)から次のようになる。

$$
k=\frac{Z \cdot\left(-\frac{\partial q_{f}}{\partial w}\right)_{x_{0}} \cdot \frac{\sigma}{A} \cdot \frac{\eta \frac{\eta t h}{(\partial W / \partial T)_{w_{0}}}}{\left(\frac{\partial T_{m}}{\partial w}\right)_{w_{0}}+\left(\frac{\partial T_{e}}{\partial w}\right)_{w_{0}}+\frac{(\partial W / \partial w)_{T_{0}}}{(\partial W / \partial T)_{w_{0}}}}}{0<k<1}
$$

自動調速装置をもつ主機関においても式(21)を満足するととが望ましい。 
$5 \cdot 2$ 低域派波器・デイーゼル機関の燃料活噴射ポンプ系および 熱力学系は場合によつては線型化が無理なような非線型性をもつて いる。すなわち、燃料泊噴射ポンプの衝程は機関回転角速度に同期 し、その有效衝程は 1 サイクル中の一定部分で燃料油は間けつ的に 気筒内に噴射され、その熱エネルギーは機械仕事に变換される。一定 回転角速度に対して機関主軸に伝達されるトルク変化は 6 気筒、 4 サイクル機関の昜合には図・10に示すようになる。しかしながら、 汐路丸の主機関は 6 気筒、4 サイクル機関であるがその回転角速度 は図・11飞示すように変化している。その周期は $2 \pi / w$ である。 この現象注各気筒の出力調整と噴射時期調整の不揃いおよび推進器 に加わるトルク変化の不同から生じたものと考えられる。一般に、 機関整備および取扱上の問題からこの回転角速度の変化の周期を常 に図・10に示すようなトルク変化の周期と等しくすることは困難で あるから、 $2 \pi / w$ 以下の 周期をもつた回転角速度变化分を帰還し ないような低域泊波器を用いれば充分であると考えら招る。图に示 されたように回転角速度の変化分は平均回転角速度 (39.22 rad/ sec）の $25 \%$ 程度である。乙の回転触速度の変化分を小さくする方 法としては次の 3 つの方法が考光られる、第1 は回転力学系の時定 数を大きくして低域派波器の作用をさせる方法、乙れを定量的に実

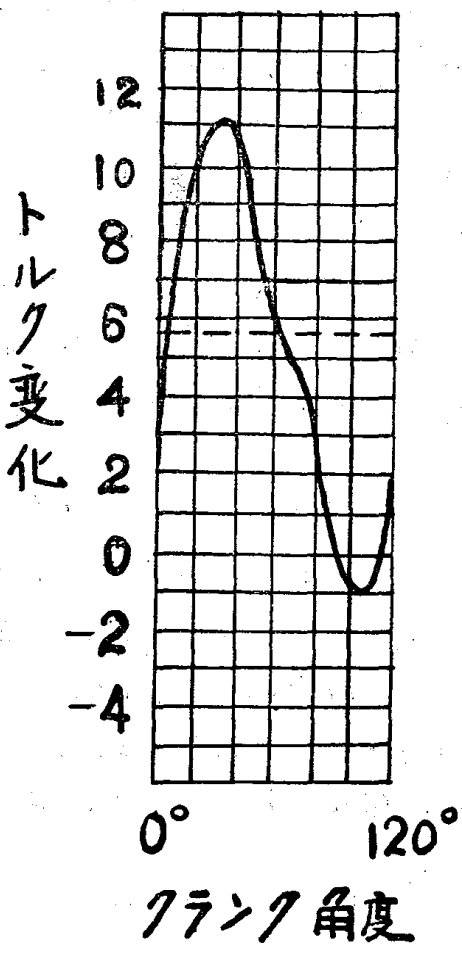

第10关 6 気筒・4サイタ ル機関のトルク変化

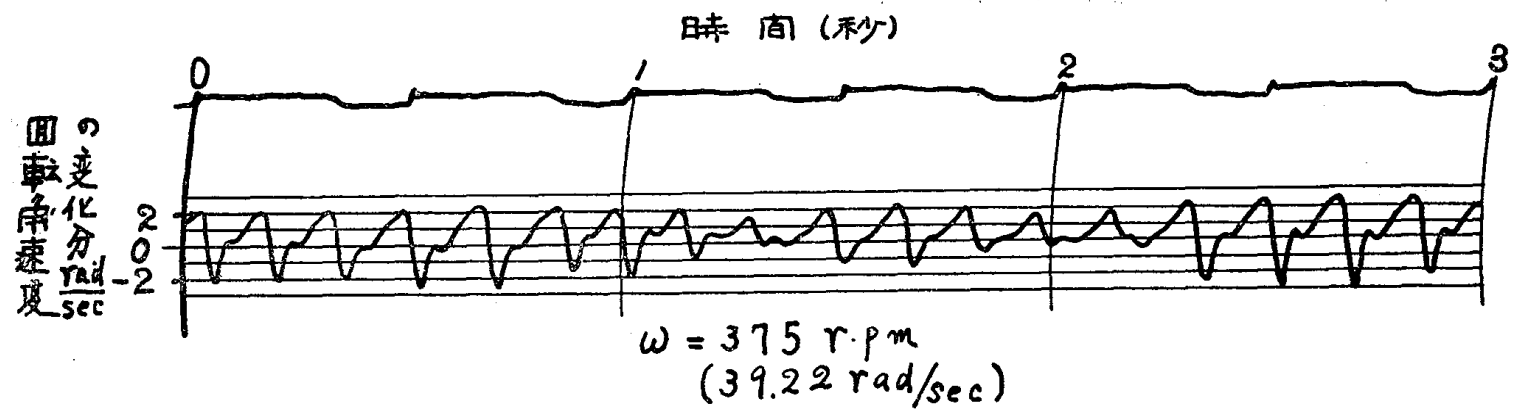

第11図 汐路丸ディーゼル主機関の回転角速度の変化

現するにはボード線図を用いて、回転力学系の慣性能率を調整すればよい。第 2 亿燃料油噴射ポ ンプ系を 4 サイクル機関よりも2 サイクル機関を選ぶ方法、第 3 亿気筒数を増加する方法があ る。汐路丸主機関に加わる負荷変化は主に船体のピツチングによるもので、その周期は最小 4 秒 程度であり、その負荷変化は最大 $70 \%$ 程度である。とのような理由から、汐路丸 $3 / 4$ 負荷時におけ る調速系に対する要求は $2 \pi / w \fallingdotseq 1 / 6$ 秒なる周期でもつて変化量が $25 \%$ 以下なる回転㢈速度の变 化仪刘して調速系は動作せず、周期 4 秒以上の回転角速度の変化に刘しては忠実に動作するとと である。汐路丸主機関を前 3 方法によつて改造するてとなくてれを実現するためにはなるべく鋭 敏にカット・オフする特性をもつた低域泊波器（回転角速度検出機構にての特性をもたせてもよ い）を用いることが考えられる。汐路丸主機閏の低域沪波器のばね䇥数を調整した結果、その時 定数を 2 秒にした。図・8に示す3/4負荷時における負荷外乱に対する回転角速度の周波数特性線

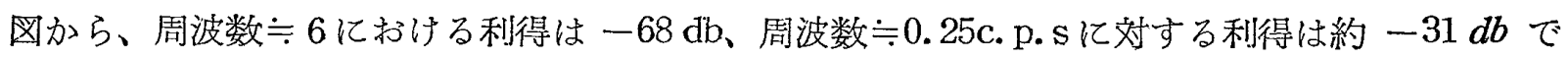
ある。その差は $37 d b$ となつているから大体において要求を満しているものと考えられる。負 荷外乱に対する回転角速度についての害験は省いたが、目標值変更に対する回転角速度について 
の過度応答実験を図・9 亿示した。図・7亿示した周波数応答計算值から求めた破線で示す計算 結果は実験結果と比較的よく近似している。

5 ・3 ゲイン定数・図・ 5 亿示す系の一巡伝達関数の $3 / 4$ 負荷時に抗りる周波数線図を図・ 6 亿 示す。ての系は要求によつて積分制御要素をもたず、オフセツトの減少対策としてはゲイン調整 のみである。3/4負何時においては現状のゲイン定数を $10 d b$ (約 3.2 倍) だけ持上げても系が適 当な安定度にあるてとが図・6からわかる。乙れからわかるように、各及の負待対してそれぞ れ適当なゲイン定数があるわけであるから、目標值の変更にともなつて、ゲイン定数を適当な值 に変更するととが望ましい。

\section{6. 結 論}

上記のように汐路丸デイーゼル主機関の自動調速系を解析し、計画および調整に対する手法を 提䓩したが、この方法は船舶用大型低速デイーゼル機関にも適用出来るものと思う。

この解析に当り、御指導を頂いた東京商船大学、赤堀昇先生、資料を御提供下された池貝鉄工 所（株）素滰哲生課長代理、石川島重工業（株）中野美樹技師、ならびに、笑験に御㶸力下され た汐路丸乗組員の方々に対して心から御礼を申上げる。

参考 文 献

1) H. F. P. Purday : Diesel Engine Design, Constable and Company LTD.

2) 高橋利衛：小型デイーゼル機関のガバナ試験、早稲田大学理工学研究所報告第 8 輯 (1958)。

3）丸山浩一・デイーゼル機関の㨭り振動、山海堂。 